\title{
OS-SR-ND-HF ISOTOPE EVIDENCE FOR THE ANCIENT DEPLETION AND SUBSEQUENT Multi-Stage EnRichment History OF THE KaAPVAAL CRATONiC lithosPhere
}

\author{
Simon NSC ${ }^{1}$, Carlson RW ${ }^{2}$, Davies GR ${ }^{1}$, Nowell GM and Pearson DG ${ }^{3}$ \\ 1 FALW, VU Amsterdam, The Netherlands, 2 DTM, Carnegie Inst. Washington, USA, 3 Dep. of Geological Sciences, Durham University UK
}

\section{ABSTRACT}

The bulk of the Kaapvaal sub-cratonic lithospheric mantle (SCLM) is accepted to have been formed as residua of large degrees of melting in the Archaean and been coupled to the crust ever since. The overall strong major element depletion, however, is not consistent their high relative modal garnet and cpx contents and the enrichment in incompatible trace elements. Numerous models have been proposed to explain these inconsistencies, mostly invoking large-scale metasomatism. However, many open questions remain concerning the style and timing of the processes that led to the modification of the SCLM.We have carried out a detailed, multi-technique study on a suite of low temperature peridotite xenoliths from Kimberley and Lesotho to better constrain these metasomatic processes and to evaluate the timing of growth and relationship between the major modal minerals.

Petrography and mineral chemical studies were performed on the samples prior to analysis. Depletion ages of the bulk xenoliths were obtained by Re-Os isotope analyses. Kimberley peridotites yield a range of $\mathrm{T}_{\mathrm{RD}}$ ages between 1.4 and $2.9 \mathrm{Ga}$ with a tight clustering around 2.7 Ga. Samples from N. Lesotho show evidence of extensive Re metasomatism in recent times, but nevertheless yield Archaean $\mathrm{T}_{\mathrm{RD}}$. Major and trace element analyses were carried out on whole rocks with the results showing the typical range of high $\mathrm{Mg}$ numbers, low $\mathrm{Al}$ and $\mathrm{Ca}$ compositions. Major and trace element traverses were performed across pyroxenes and garnets to evaluate the extent of element zonation. In most samples, zoning was found to be minor. In a few samples, particularly those from N. Lesotho, clinopyroxene and garnet display strong trace element disequilibria. Garnet and clinopyroxene separates were analysed for $\mathrm{Lu}-\mathrm{Hf}, \mathrm{Sm}-\mathrm{Nd}$ and $\mathrm{Rb}-\mathrm{Sr}$ isotopic composition. Most samples plot well above the mantle Nd-Hf array with many garnets having extremely positive $\varepsilon \mathrm{Hf}$ coupled with slightly negative $\mathrm{eNd}$. Cpx plot closer to kimberlite compositions in Hf-Nd isotope space. Many garnet-cpx pairs display inverse $\mathrm{Sm}-\mathrm{Nd}$ and $\mathrm{Lu}-\mathrm{Hf}$ isotope disequilibrium and parent-daughter isotope ratios are de-coupled. Therefore, mineral isochrons contain no geologically significant age information. This conclusion is in contrast to recent models that propose a progressive cooling of the SCLM beneath the Kaapvaal craton.

These results allow us to propose a model for formation and modification of the Kaapvaal lithosphere that involves at least two stages of metasomatism. The first, ancient one is preserved in some garnets, mainly of harzburgitic paragenesis, whereas the second, relatively recent one, introduced a significant portion of the cpx with or without phlogopite. This second event was probably linked to fluids associated with the host kimberlite and/or similar precursor magmas. Some of the xenoliths from Kimberley and Lesotho, with younger $\mathrm{T}(\mathrm{RD})$ ages $(2.5-1 \mathrm{Ga})$ and more fertile compositions, are interpreted as cumulates or strongly modified wall rock in or adjacent to conduits of percolating melts. These rocks also have distinct trace element and isotope compositions and might provide us with further information about the nature of the metasomatic melts during ancient metasomatism.

\section{RESULTS AND DISCUSSION}

\section{SAMPLE DESCRIPTION}

More than 40 kimberlite xenoliths from northern Lesotho and the Kimberley cluster (Old Boshoff Road dump) were studied in thin section. The sample suite is dominated by coarse garnet lherzolites with minor garnet-spinel lherzolites, garnet harzburgites and few spinel lherzolites and harzburgites. All samples belong to the low-temperature group $\left(\mathrm{T}<1100{ }^{\circ} \mathrm{C}\right)$ and are undeformed. Some samples from Lesotho contain remnants of kimberlitic material and late stage minerals (mainly cpx, phlogopite and spinel) as interstitial grains and in veins. These phases are believed to have crystallized from the host kimberlite or formed by reaction between infiltrating kimberlite and peridotite during eruption. Such features are particularly common in Lesotho xenoliths and testify to a strong interaction between kimberlite and peridotite xenoliths. This interaction is also evident from the often strongly kelyphitized garnets and the high Re contents measured in many Lesotho xenoliths. Kimberley samples are less affected by this late stage contamination and commonly have very low Re contents accompanied by less kelyphitization of garnets. Both sample suites show signs of modal metasomatism pre-dating the kimberlite 
eruption. Phlogopite is common in Lesotho and Kimberley xenoliths. Amphibole is absent in the Lesotho samples but can be found as porphyroblasts $(\sim 1 \mathrm{~mm})$ and as an interstitial late stage phase in Kimberley xenoliths, with or without phlogopite.

Two samples (one from each suite) are texturally distinct from the others in that they are much finer grained and contain abundant opaque phases (ilmenite, sulfides) in addition to the garnet lherzolite assemblage olivine + opx + cpx + garnet. Their major and trace element composition is much more fertile than those of the other samples and they are characteristically more Fe-rich. Similar samples were described from the Matsoku kimberlite pipe in Lesotho (Harte et al., 1987) and referred to as IRPS-suite. We also observe similar characteristics in one sample from Kimberley (K3). These samples may represent former melt veins or wall rock adjacent to melt conduits.

Another group of samples from Kimberley differs more subtly from the bulk of the xenoliths. The minerals are intimately intergrown and garnet and cpx are texturally equilibrated. The minerals often have convex-concave grain boundaries. These samples may or may not contain porphyroblastic phlogopite. For a detailed description of the Lesotho samples see Irvine et al. (2001) and Simon et al. (2003).

\section{WHOLE ROCKS}

\section{Major and trace elements and Re-Os isotopes}

Whole rock powders were analyzed for major and minor elements by XRF and for trace elements by ICPMS. Major element compositions of the xenoliths are generally strongly depleted in magmaphile elements, with the exception of the more fertile samples mentioned above (M1, K3, K19, K21). Most xenoliths also have the high $\mathrm{Si} / \mathrm{Mg}$ ratios, typical for Kaapvaal peridotites, which is reflected in their high opx contents (19-45\%, mean: 30\%). Garnet and cpx contents are generally low (means 5.7 and $2.1 \%$, respectively), with $0-19 \%$ cpx and $1.4-21 \%$ garnet in Kimberley peridotites, and $0.4-3.9 \% \mathrm{cpx}$ and $0.1-7.7 \%$ garnet in the Lesotho rocks. Most samples follow a general melt depletion trend in a $\mathrm{CaO}$ vs. $\mathrm{Al}_{2} \mathrm{O}_{3}$ diagram, with some appearing to be preferentially enriched in $\mathrm{Al}$ or $\mathrm{Ca}$ relative to their $\mathrm{Si} / \mathrm{Mg}$ ratio $(\mathrm{K} 3, \mathrm{~K} 19, \mathrm{~K} 21, \mathrm{GP} 402$, M1). These are the same samples that were previously noted to be texturally distinct. The spread in major element compositions is much larger for the Kimberley suite than for Lesotho, but both suites record a wide range of whole rock compositions from very depleted spinel harzburgites to fertile garnet lherzolites.

Trace element compositions for whole rocks (WR) measured by ICP are difficult to interpret unambiguously since the petrography reveals that the xenoliths have been clearly contaminated by infiltrating kimberlite. Thus, we reconstructed the whole rock trace element composition from mineral compositions and modes and compared those to the measured whole rock trace element contents. Whereas the measured WR trace element patterns are variably, but generally strongly enriched in incompatible trace elements, the reconstructed WR patterns are depleted in all trace elements relative to primitive mantle (except "fertile" samples M1, K3 and K21). The difference is readily explained by $1-4 \%$ addition of kimberlite to the whole rock. The general shape of the reconstructed whole rock patterns resembles those of the garnets in the same samples (see following section) in that they are often sigmoidal with a primitive mantle normalized maximum at Nd-Sm. In summary, it is important to note that the bulk of the peridotite xenoliths have trace element contents lower than primitive mantle and are not as enriched in incompatible elements as suggested by measured WR trace element contents. The reconstructed patterns, however, are not typical of depleted mantle either, but reflect strong depletion still preserved in the HREE, followed by incompatible element enrichment that is particularly pronounced for the MREE.

The extensive melt depletion is also evident in the ReOs isotopic signature of the whole rocks. The xenoliths from Kimberley, in particular, have generally very low Re contents and therefore similar Re model ages ( $\mathrm{T}_{\mathrm{MA}}$, conventional Re-Os model age) and Re-depletion minimum ages $\left(\mathrm{T}_{\mathrm{RD}}\right.$, Re is assumed to be quantitatively removed during melting and the measured ${ }^{187} \mathrm{Os} /{ }^{188} \mathrm{Os}$ ratio is used for age calculation without correction for Re). Many xenoliths from Lesotho suffered from significant recent Re-addition by the host kimberlites, but still preserve ancient $\mathrm{T}_{\mathrm{RD}}$ ages. $\mathrm{T}_{\mathrm{RD}}$ ages for both suites are generally Archaean (mean: $2.7 \mathrm{Ga}$, max age up to $3.5 \mathrm{Ga}$ ), confirming earlier results from the Kaapvaal craton (Pearson et al., 1995; Carlson et al., 1999; Irvine et al., 2001). Some samples have significantly younger Re-Os ages, which in many cases coincide with differences in textures and chemical compositions and appear to imply magmatic events that post-date Archaean melt depletion. 


\section{MINERALS}

\section{Major and trace elements}

Minerals were analyzed for major elements by EPMA and for traces by Laser ablation ICP-MS and/or ion probe (SIMS). Major and trace element profiles were measured to check for mineral zoning. Minerals are usually quite homogeneous in major elements but might show some variation in traces. Zonation in REE was particularly common in garnets from the Lesotho samples, but is usually restricted to the outermost rim (max. $200 \mu \mathrm{m}$ ) of the grains. The REE zonation in garnets is interpreted as re-equilibration with cpx since garnet REE patterns develop from sigmoidal in the cores (which are not consistent with garnet/cpx equilibrium partitioning) to patterns with (LREE, $\mathrm{MREE})_{\mathrm{N}}<(\mathrm{HREE})_{\mathrm{N}}$ in the rims $\left(\mathrm{D}^{\mathrm{g} / \mathrm{cpx}}\right.$ reach or approach equilibrium values). An extended discussion of garnet and cpx major and trace element systematics of the Lesotho samples can be found in Simon et al. (2003).

The variation in cpx trace element concentrations is much more restricted than in garnets, especially in the Lesotho samples. All cpx are LREE enriched with C1normalized maxima at $\mathrm{Ce}-\mathrm{Nd}$ and have variable negative HFSE anomalies. Kimberley cpx's show some variation in HREE and $\mathrm{K} 19$ and $\mathrm{K} 21$ have $\mathrm{La}_{\mathrm{N}} \sim \mathrm{Ce}_{\mathrm{N}}$ and $(\mathrm{Ce} / \mathrm{Nd})_{\mathrm{N}}>1$.

Garnets and cpx's in xenoliths from Kimberley are more equilibrated than those from Lesotho. Even though most garnets have sigmoidal REE patterns, $\mathrm{D}_{\text {REE }}^{\mathrm{gt} / \mathrm{cpx}}$ are roughly consistent with equilibrium partitioning. In both sample suites, garnets from (cpxfree) harzburgites show the strongest enrichment in MREE $\left((\mathrm{Sm} / \mathrm{Nd})_{\mathrm{N}}<1\right)$ and high Lu/Hf ratios. Garnets from the more fertile and texturally (and REE) equilibrated samples have the highest $\mathrm{Lu} / \mathrm{Hf}$ and high $\mathrm{Sm} / \mathrm{Nd}$ ratios.

\section{Rb-Sr, Sm-Nd and Lu-Hf isotope systems}

Clean and transparent garnets and cpx's from selected samples were carefully handpicked and leached before dissolution. In samples where trace element zonation in garnet was observed, we tried to avoid garnet rims during picking. The solutions were totally spiked and processed following standard techniques to obtain fractions for isotope analyses by TIMS ( $\mathrm{Sr}, \mathrm{Sm}, \mathrm{Nd}$ ) and MC-ICP-MS (Rb, Sm, Nd, Lu, Hf). Chemistry and analyses were carried out at the Department of Terrestrial Magnetism (Washington, DC), Vrije Universiteit Amsterdam and the University of Durham.
An overview of the isotopic ranges obtained for garnet and cpx's and values for representative kimberlites from Kimberley (Nowell et al., 2003) are given in Figure 1.

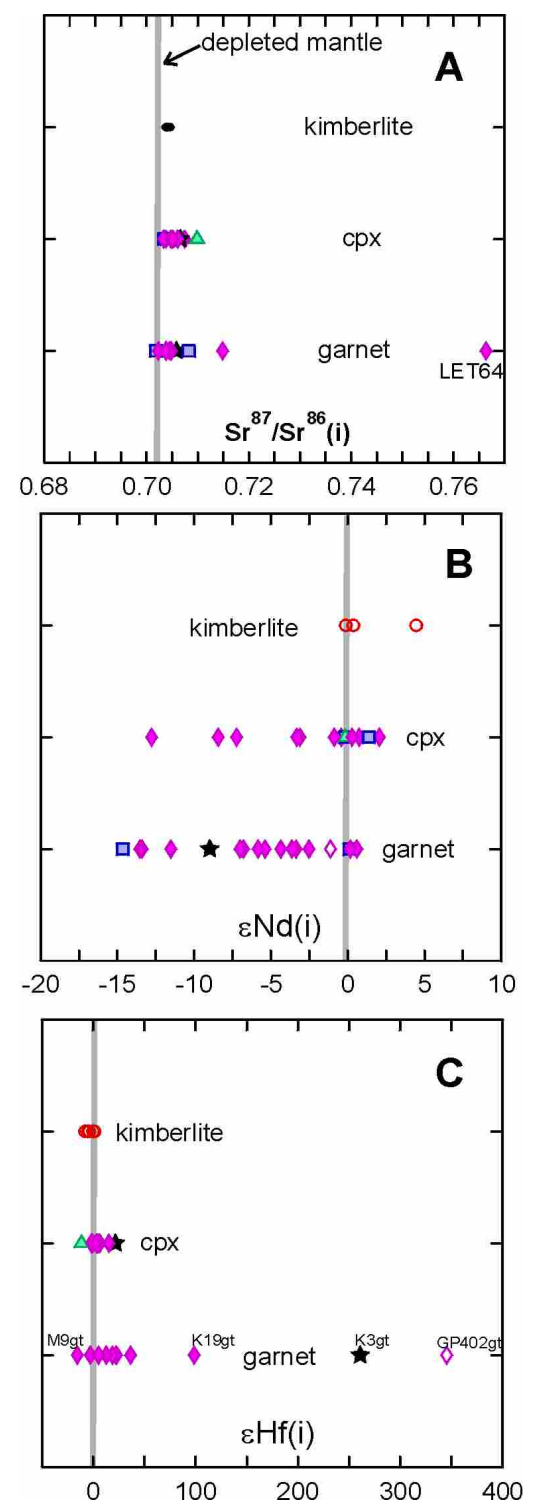

Figure 1: Range of isotope ratios in garnets and cpx. A: ${ }^{87} \mathrm{Sr} /{ }^{86} \mathrm{Sr}(\mathrm{i}) . \mathbf{B}: \varepsilon \mathrm{Nd}(\mathrm{i}) . \mathbf{C}: \varepsilon \mathrm{Hf}(\mathrm{i})$.

Most garnets and cpx have a narrow range of $\mathrm{Sr}^{87} /{ }^{86} \mathrm{Sr}$ (i) higher than depleted mantle (Fig 1A) and higher or similar to kimberlite (Nowell et al., 2003). One garnet from Letseng (LET64) has very radiogenic initial $\mathrm{Sr}$ isotope ratios (0.76637). It is likely that the $\mathrm{Sr}$ isotope composition of most of the xenoliths was significantly affected by the kimberlite and was reset in most cases. Consequently, little information could be obtained from the $\mathrm{Rb}-\mathrm{Sr}$ system. For example, garnet- 
cpx 2-point $\mathrm{Rb}-\mathrm{Sr}$ isochron ages are close to 0 or even negative.

Garnet and cpx display a large range in $\mathrm{Nd}$ isotope ratios (Fig. 1B). Most garnets have negative $\varepsilon N d(i)$ as low as -15 , but range to +2.4 . Cpx are on average more radiogenic with $\varepsilon \mathrm{Nd}(\mathrm{i})$ ranging from -13 to 2.3 . The majority of cpx have $\varepsilon N d(i)$ in the range -1 to 2.3 . The negative $\varepsilon \mathrm{Nd}$ in some cpx is not surprising since they are all LREE enriched and have $(\mathrm{Sm} / \mathrm{Nd})_{\mathrm{N}} \ll 1$. Unradiogenic Nd was previously found in garnets from Kaapvaal peridotites and interpreted as indicating long term LREE enrichment (e.g., Richardson et al., 1984; Richardson et al., 1985). Negative $\varepsilon N d(i)$ is consistent with the most sigmoidal REE patterns (low $\mathrm{Sm} / \mathrm{Nd}$ ) found in garnets in this sample suite. Alternatively, negative $\varepsilon N d$ could also originate from (partial) reequilibration with unradiogenic $\mathrm{Nd}$ in cpx. This was probably the case in samples K3, K21 and K19, where garnets have REE patterns with $(\mathrm{LREE} / \mathrm{HREE})_{\mathrm{N}} \sim 0.01$ $\left((\mathrm{Sm} / \mathrm{Nd})_{\mathrm{N}}>1\right)$ but the co-existing cpx have very negative $\varepsilon \mathrm{Nd}$ (due to very low $\mathrm{Sm} / \mathrm{Nd}$ ratios). For the other samples we argue that low $\varepsilon \mathrm{Nd}$ in garnets reflect the ancient light and middle REE enrichment experienced by these samples (in accordance with Richardson et al., 1985). This hypothesis is strongly supported by the fact that all garnet-cpx pairs from Lesotho display negative slopes in a $\mathrm{Sm}-\mathrm{Nd}$ isochron diagram (i.e., isotopic disequilibrium). This clearly demonstrates that garnets and cpx's are not equilibrated and most likely were introduced during different events. This observation also shows that the negative $\varepsilon N d(i)$ in the Lesotho garnets cannot be caused by reequilibration with (more unradiogenic) $\mathrm{Nd}$ in cpx. Therefore, we conclude that garnets in the Lesotho samples are ancient and experienced long term enrichment, whereas the cpx were introduced significantly later. Ambient conditions were such that trace element and isotopic equilibria could not be reached while major elements seem to have achieved equilibrium.

As was shown above, based on the trace element systematics, garnet and cpx in the Kimberley samples appear to be more equilibrated than in the Lesotho xenoliths. Consequently, only one sample yields a negative garnet-cpx isochron age. All other samples yield 2-point isochron ages between 25 and $202 \mathrm{Ma}$. In many Kimberley garnets, however, the $\mathrm{Nd}$ isotope ratios are not supported by the $\mathrm{Sm} / \mathrm{Nd}$ ratios and parent- daughter ratios are decoupled. These relationships indicate a similar origin for diopside and garnet as that proposed for the Lesotho samples, i.e., the garnets in the Kimberley xenoliths are old and enriched, and cpx's were introduced during a later event. The less evident disequilibrium in the Kimberley samples might be due to storage of the xenoliths at higher temperatures or a longer period of co-existence of garnet and cpx, e.g., cpx was introduced earlier in the mantle underlying Kimberley than Lesotho. Alternatively, the Kimberley lithosphere might be more fluid-rich and hence undergo faster inter-mineral diffusion. This is supported by the more abundant hydrous metasomatic phases and assemblages such as MARID in kimberlite xenoliths from the Kimberley area.

Hf isotope compositions of cpx are relatively restricted $(\varepsilon \mathrm{Hf}(\mathrm{i})=-11$ to +22$)$ compared to garnets $(\varepsilon \mathrm{Hf}(\mathrm{i})=-16$ to +345 ; Fig. 1C). All but two garnets (M9 and K1) have positive $\varepsilon \mathrm{Hf}(\mathrm{i})$. The most radiogenic Hf was found in the only harzburgitic garnet analyzed from Kimberley (GP402). 2-point Lu-Hf isochron ages range from negative ages (M9) to $1.9 \mathrm{Ga}$ for Lesotho and 0.31 to $0.84 \mathrm{Ga}$ for Kimberley. In many cases, parent daughter ratios are decoupled and the ${ }^{176} \mathrm{Hf} /{ }^{177} \mathrm{Hf}$ ratio is not supported by the ${ }^{176} \mathrm{Lu} /{ }^{177} \mathrm{Hf}$ ratio. The generally very radiogenic $\mathrm{Hf}$ in garnet reflects the ancient melt depletion of the lithosphere that resulted in high $\mathrm{Lu} / \mathrm{Hf}$ in the garnets and in the whole rocks if cpx is absent. The Hf isotopic signature, however, was probably disturbed during ancient LREE enrichment of the mantle, but remained greater than Bulk Earth. Introduction of cpx and partial equilibration between cpx and garnet further blurred the original Lu-Hf signature. We therefore can attach no geological significance to the Lu-Hf model or isochron ages. Bedini et al. (2002) and Albarède et al. (2002) suggested that the differences observed between $\mathrm{Sm}-\mathrm{Nd}$ and Lu-Hf garnet-cpx isochron ages and the range in ages reflect different closure temperatures of the isotopic systems and a slow cooling of the Kaapvaal lithosphere since the Archaean. Their model is based on a correlation between Lu-Hf isochron ages and 2pyroxene temperatures observed for 5 samples from Kaapvaal. We find no correlation between $\mathrm{Lu}-\mathrm{Hf}$ isochron ages and temperatures (independent of the geothermobarometer used) for the much larger sample suite studied here (Fig. 2). 


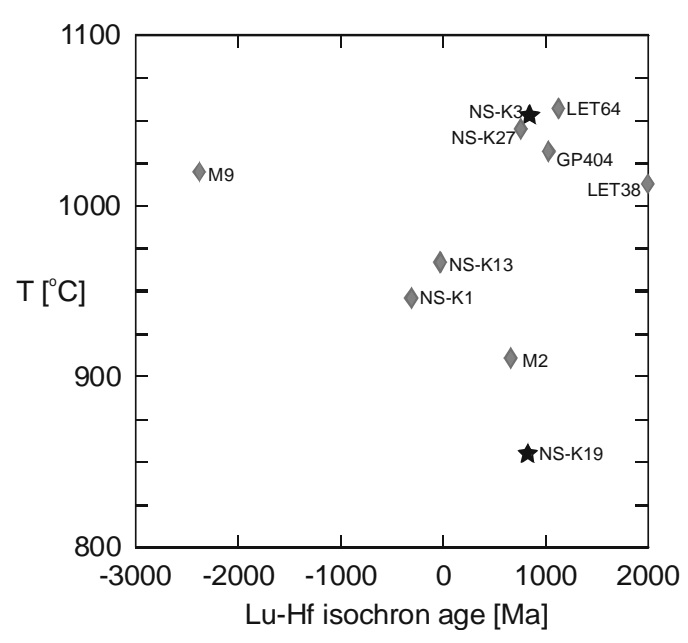

Figure 2: Calculated temperatures (olivine-garnet) vs. garnet-cpx isochron ages.

\section{CONCLUSIONS}

Textural observations combined with major and trace element and Os-Sr-Nd-Hf isotope measurements indicate a complex multi-stage evolution of the Kaapvaal SCLM.

(1) Extensive melting in the Archaean causes strong depletion of a pyrolite mantle. Cpx is exhausted. The whole rock isotopic evolution is dominated by garnets with very high $\mathrm{Lu} / \mathrm{Hf}$ and $\mathrm{Sm} / \mathrm{Nd}$ ratios that evolve towards radiogenic $\mathrm{Hf}$ and $\mathrm{Nd}$.

(2) The residual harzburgite is re-enriched in incompatible trace elements. $\mathrm{Sm} / \mathrm{Nd}$ ratios are lowered to sub-chondritic causing unradiogenic $\mathrm{Nd}$ with time. Lu/Hf is also lowered but remains > chondritic. Most samples remain harzburgitic (cpxfree).

(3) The system is disturbed and partially reset by a metasomatic event that introduces cpx \pm other metasomatic phases. The minerals re-equilibrate to different extents.

(4) Entrainment of the xenoliths and eruption of the kimberlite takes place around $90 \mathrm{Ma}$ and causes a last modification of the xenoliths.

The geochemistry of peridotite xenoliths differs significantly between Kimberley (craton core) and Lesotho (craton edge) and also within a single location. Garnet and cpx in most if not all xenoliths studied here are not co-genetic and only partially equilibrated in most cases. Ages obtained from garnet-cpx pairs (as well as temperatures) are not geologically significant. Diopsides and garnets from the peridotites display a wide range of $\mathrm{Nd}$ and $\mathrm{Hf}$ isotope compositions. The majority of phases, however, have strongly positive $\varepsilon H f$ and negative $\varepsilon N d$ and we therefore suggest that the bulk of the Kaapvaal lithosphere plots in the upper left quadrant of a Nd-Hf isotope diagram, well above the mantle array.

\section{REFERENCES}

Albarède, F., Bedini, R.-M., Blichert-Toft, J., Boyet, M., 2002. Sm-Nd and Lu-Hf ages of ultramafic xenoliths from South African kimberlites and the secular cooling of the Earth. Eos Transactions of the American Geophysical Union, 83(47 (Fall Meeting Supplement)): Abstract MR71B-05.

Bedini, R.M., Blichert-Toft, J., Boyet, M., Albarède, F., 2002. Lu-Hf isotope geochemistry of garnet-peridotite xenoliths from the Kaapvaal craton and the thermal regime of the lithosphere. Abstract. Geochimica et Cosmochimica Acta, Special Supplement abstracts 12th Goldschmidt Conference, Davos, 66(15A): A61.

Carlson, R.W., Pearson, D.G., Boyd, F.R., Shirey, S.B., Irvine, G., Menzies, A.H., Gurney, J.J., 1999. Re-Os systematics of lithospheric peridotites: implications for lithosphere formation and preservation, Proceedings of the 7th International Kimberlite Conference, Cape Town, 1998. Red Roof Design, Cape Town, South Africa, pp. 99-108.

Harte, B., Winterburn, P.A., Gurney, J.J., 1987. Metasomatic and enrichment phenomena in garnet peridotite facies mantle xenoliths from the Matsoku kimberlite pipe, Lesotho. In: M. Menzies (Editor), Mantle metsasomatism. Academic Press Inc., London, pp. 145220.

Irvine, G.J., Pearson, D.G., Carlson, R.W., 2001. Lithospheric mantle evolution of the Kaapvaal Craton: a Re-Os isotope study of peridotite xenoliths from Lesotho kimberlites. Geophysical Research Letters, 28(13): 25052508.

Nowell, G., Pearson, D., Bell, D., Carlson, R., Smith, C., Kempton, P., Noble, S., 2003. Hf isotope systematics of kimberlites and their megacrysts: new constraints on their source regions. Journal of Petrology, in press.

Pearson, D.G., Carlson, R.W., Shirey, S.B., Boyd, F.R., Nixon, P.H., 1995. Stabilization of Archean Lithospheric Mantle: A Re-Os Isotope Study of Peridotite Xenoliths From the Kaapvaal Craton. Earth and Planetary Science Letters, 134(3-4): 341-357.

Richardson, S., Erlank, A., Hart, S., 1985. Kimberlite-borne garnet peridotite xenoliths from old enriched subcontinental lithosphere. Earth and Planetary Science Letters, 75: 116-128.

Richardson, S., Gurney, J., Erlank, A., Harris, J., 1984. Origin of diamonds from old continental mantle. Nature, 310: 198-202.

Simon, N.S.C., Irvine, G.J., Davies, G.R., Pearson, D.G., Carlson, R.W., 2003. The origin of garnet and clinopyroxene in "depleted" Kaapvaal peridotites. Lithos, in press.

Contact: NSC Simon, FALW, Vrije Universiteit Amsterdam, De Boelelaan 1085, 1081 HV Amsterdam, The Netherlands, E-mail: nina.simon@falw.vu.nl 